\title{
SYSTEM RELIABILITY REGULATION THROUGH SENSITIVITY FACTOR
}

\author{
感度係数による系信頼度の調節 \\ Sadaichi TERADA* and Takafumi MOROI** \\ 寺田貞一, 諸井孝文
}

This paper develops a method to design a system that has prescribed reliability adjusting the capacity of suitably chosen element(s) directed by the sensitivity factor. The sensitivity factors for the reliability index generally work better than those for the failure probability. Approximate sensitivity factors in the examples afford the prescribed system reliabilities through simple calculation. Some additional calculatıons over ordinary reliability analysis are more than enough to attain the purpose.

Keywords: Performance function, Reliability adjustment, Sensitivity factor, System, Target reliability 性能関数, 信頼度調整, 感度係数, 系, 目標信頼度

\section{INTRODUCTION}

To ensure the prescribed reliability for steel structures, the load and resistance factor design known as LRFD has been developed ${ }^{12)}$. It ensures the prescribed reliability for the structural members and their joints to specified loads and their combinations. However, even if some members in a structure may fail, the system often survives as a whole. Therefore there needs a method to ensure the prescribed system reliability. This paper develops a simple method to attain the object adjusting the capacity of suitably chosen member(s) directed by the sensitivity factor.

\section{SENSITIVITY FACTOR}

In order to calculate the importance factor, the sensitivity factor of a parameter $\theta$ for the failure probability $\Phi\left(-\beta_{S}\right)$ of.a system is defined by the differential that

$$
\gamma_{1, \theta}=\frac{d \Phi(-\beta s)}{d \theta}
$$

where $\gamma_{1, \theta}=$ the sensitivity factor of $\theta$ for $\Phi\left(-\beta_{s}\right), \beta_{s}=$ the system reliability index, and $\Phi(\cdot)=$ the standard normal cumulative distribution function $^{3)}$ 4).

Another sensitivity factor of $\theta$ for $\beta_{s}$ is defined by

$$
\gamma_{2, \theta}=\frac{d \beta_{S}}{d \theta}=\frac{-1}{\phi\left(-\beta_{S}\right)} \frac{d \Phi\left(-\beta_{S}\right)}{d \theta}=\frac{-1}{\phi\left(-\beta_{S}\right)} \gamma_{1, \ddot{\theta}}
$$

where $\phi(\cdot)=$ the standard normal probability density function.

The parameter $\theta_{T}$ that attains the target $\Phi\left(-\beta_{T}\right)$ or $\beta_{T}$ can be obtained by the following equations.

* Prof Emeritus, Tokyo Metropolitan Univ, Dr Eng

東京都立大学 名誉教授・工博

** Kobori Research Complex, Kajima Corporation 


$$
\Phi\left(-\beta_{T}\right)-\Phi\left(-\beta_{S}^{(0)}\right)=\left(\theta_{T}-\theta^{(0)}\right) \gamma_{1, \theta}
$$

or

$$
\beta_{T}-\beta_{S}^{(0)}=\left(\theta_{T}-\theta^{(0)}\right) \gamma_{2, \theta}
$$

where $\beta_{s}{ }^{(0)}$ and $\theta^{(0)}$ are $\beta_{s}$ and $\theta$ of the preliminary design, respectively.

The sensitivity factor $\gamma_{1, \Phi(-\beta,)}$ works well because it has the same unit as $\Phi\left(-\beta_{S}\right)$, in which $\beta_{1}=$ the reliability index of basic failure event $F$. Though both $\Phi\left(-\beta_{s}\right)$ and $\beta_{s}$ are nonlinear function of the average $\mu$ and standard deviation $\sigma$ of a basic random variable, variation of $\gamma_{1, \theta}$ accompanied by the increase of $\mu$ and $\sigma$ is larger than that of $\gamma_{2, \theta}$. Therefore, the sensitivity factor $\gamma_{2, \theta}$ is preferable for the parameters $\mu$ and $\sigma$.

\section{PARALLEL SYSTEMS}

The failure event $F_{S}$ of a parallel system is expressed by the intersection of basic failure events $F_{l}(i=1,2$. $n)$; that is, $F_{S}=F_{1} \cap F_{2} \cap \cdot \cap F_{n}$. Its failure probability is expressed by

$$
\Phi\left(-\beta_{S}\right)=\Phi\left(-\beta_{1} 2_{n} \quad{ }_{n}\right)=\Phi\left(-\beta_{1}\right) \Phi\left(-\beta_{23} \quad{ }_{n 11}\right)=\Phi\left(-\beta_{1}\right) \Psi=\Phi\left(-\beta_{1}\right) \Phi\left(-\beta_{211}\right) \Phi\left(-\beta_{3112}\right) \quad . \Phi\left(-\beta_{n \mid 12} \quad(n-1)\right.
$$

where

$$
\begin{aligned}
& \Psi=\Phi\left(-\beta_{23}{ }_{n 11}\right)=\Phi\left(-\beta_{S}\right) / \Phi\left(-\beta_{1}\right), A_{1}=\phi\left(-\beta_{1}\right) / \Phi\left(-\beta_{1}\right), \quad B_{1}=A_{1}\left(\beta_{1}-A_{1}\right), \\
& \beta_{211}=\left(\beta_{2}-\rho_{12} A_{1}\right) / \sqrt{1+\rho_{12}^{2} B_{1}}, A_{211}=\phi\left(-\beta_{211}\right) / \Phi\left(-\beta_{211}\right), \quad B_{211}=A_{211}\left(\beta_{211}-A_{211}\right), \\
& \beta_{3112}=\frac{\beta_{311}-\rho_{2311} A_{211}}{\sqrt{1+\rho_{2311}^{2} B_{211}}}=\left.\frac{\beta_{3}-\rho_{23} A_{2}}{\sqrt{1+\rho_{23}^{2} B_{2}}}\right|_{1}, \quad \rho_{2311}=\frac{\rho_{12} \rho_{13} B_{1}+\rho_{23}}{\sqrt{\left(1+\rho_{12}^{2} B_{1}\right)\left(1+\rho_{13}^{2} B_{1}\right)}}
\end{aligned}
$$

and the like ${ }^{5)}$. The symbol $\rho_{\imath \jmath}$ above denotes the correlation coefficient between $F_{1}$ and $F_{\text {j }}$.

Probable errors in the calculation depend on ordering of the reliability indices. Practical experience suggests ordering that $\beta_{1} \geq \beta_{2} \geq \beta_{3} \geq \cdots \geq \beta_{n}$. The failure probability $\Phi\left(-\beta_{s}\right)$ in Eq.(5) is differentiated by $\theta$ as follows.

$$
\gamma_{1, \theta}=\frac{d \Phi\left(-\beta_{S}\right)}{d \theta}=\frac{\partial \Phi\left(-\beta_{S}\right)}{\partial \Phi\left(-\beta_{1}\right)} \frac{d \Phi\left(-\beta_{1}\right)}{d \theta}+\frac{\partial \Phi\left(-\beta_{S}\right)}{\partial \Phi\left(-\beta_{211}\right)} \frac{d \Phi\left(-\beta_{211}\right)}{d \theta}+\frac{\partial \Phi\left(-\beta_{S}\right)}{\partial \Phi\left(-\beta_{3112}\right)} \frac{d \Phi\left(-\beta_{3112}\right)}{d \theta}+\cdots
$$

Since $\partial \Phi\left(-\beta_{S}\right) / \partial \Phi\left(-\beta_{1}\right)=\Phi\left(-\beta_{S}\right) / \Phi\left(-\beta_{1}\right)=\psi$, and $d \Phi\left(-\beta_{1}\right) / d \theta=\left[\partial \Phi\left(-\beta_{1}\right) / \partial \beta_{1}\right]\left(d \beta_{1} / d \theta\right)=-\phi\left(-\beta_{1}\right)\left(d \beta_{1} / d \theta\right)$, the sensitivity factor of $\theta$ for $\Phi\left(-\beta_{S}\right)$ is expressed by

$$
\gamma_{1, \theta}=\frac{d \Phi\left(-\beta_{S}\right)}{d \theta}=-\psi \phi\left(-\beta_{1}\right) \frac{d \beta_{1}}{d \theta}\left[1+\frac{A_{211}}{A_{1}} \frac{d \beta_{211}}{d \beta_{1}}+\frac{A_{3112}}{A_{1}} \frac{d \beta_{3112}}{d \beta_{1}}+\cdots\right]=-\psi \phi\left(-\beta_{1}\right) \frac{d \beta_{1}}{d \theta} \zeta
$$

where

$$
\zeta=1+\frac{A_{2 \mid 1} d \beta_{211}}{A_{1}} d \beta_{1}+\frac{A_{3 \mid 12}}{A_{1}} \frac{d \beta_{3112}}{d \beta_{1}}+\cdots
$$

If $\theta=\Phi\left(-\beta_{1}\right)$, then

$$
\gamma_{1, \Phi\left(-\beta_{1}\right)}=\psi \zeta
$$

Substituting Eq.(7) into Eq.(2), the following sensitivity factors for $\beta_{S}$ are obtained.

$$
\gamma_{2, \theta}=\frac{d \beta_{S}}{d \theta}=\frac{-1}{\phi\left(-\beta_{S}\right)} \frac{d \Phi\left(-\beta_{S}\right)}{d \theta}=\frac{A_{1}}{A_{S}} \frac{d \beta_{1}}{d \theta} \zeta
$$

and

$$
\gamma_{2, \beta_{1}}=\frac{d \beta_{S}}{d \beta_{1}}=\frac{A_{1}}{A_{S}} \zeta
$$

Since $\beta_{211}=f\left(\beta_{1}, \beta_{2}, \rho\right), d \beta_{211} / d \theta$ is represented as

$$
\frac{d \beta_{2 \mid 1}}{d \theta}=\frac{\partial \beta_{211}}{\partial \beta_{1}} \frac{d \beta_{1}}{d \theta}+\frac{\partial \beta_{2 \mid 1}}{\partial \beta_{2}} \frac{d \beta_{2}}{d \theta}+\frac{\partial \beta_{2 \mid 1}}{\partial \rho} \frac{d \rho}{d \theta}
$$

Entering $\partial A_{1} / \partial \beta_{1}=-B_{1}$ and $\partial B_{1} / \partial \beta_{1}=A_{1}+B_{1}\left(2 A_{1}-\beta_{1}\right)$ into the equation, the differential is expressed by

$$
\frac{d \beta_{211}}{d \theta}=\frac{\rho_{12} C_{12} \frac{d \beta_{1}}{d \theta}+\frac{d \beta_{2}}{d \theta}-\frac{A_{1}+\rho_{12} B_{1} \beta_{211}}{\sqrt{1+\rho_{12}^{2} B_{1}}} \frac{d \rho}{d \theta}}{\sqrt{1+\rho_{12}^{2} B_{1}}}
$$

where $\quad C_{12}=B_{1}-\frac{\rho_{12} \beta_{211}\left[A_{1}+B_{1}\left(2 A_{1}-\beta_{1}\right)\right]}{2 \sqrt{1+\rho_{12}^{2} B_{1}}}$ 
Similarly, the differential $d \beta_{312} / d \theta$ approximates to

$$
\frac{d \beta_{3112}}{d \theta}=\frac{\rho_{2311} C_{2311} \frac{d \beta_{211}}{d \theta}+\frac{d \beta_{311}}{d \theta}-D_{2311} \frac{d \rho_{2311}}{d \theta}}{\sqrt{1+\rho_{2311}^{2} B_{211}}}
$$

where

and

$$
\begin{aligned}
& C_{2311}=B_{211}-\frac{\rho_{2311} \beta_{3112}\left[A_{211}+B_{211}\left(2 A_{211}-\beta_{211}\right)\right]}{2 \sqrt{1+\rho_{2311}^{2} B_{211}}} \\
& D_{2311}=A_{211}+\frac{\rho_{2311} \beta_{3112} B_{211}}{\sqrt{1+\rho_{2311}^{2} B_{211}}}
\end{aligned}
$$

$$
\frac{d \rho_{2311}}{d \theta}=\frac{A_{1}+B_{1}\left(2 A_{1}-\beta_{1}\right)}{\sqrt{\left(1+\rho_{12}^{2} B_{1}\right)\left(1+\rho_{13}^{2} B_{1}\right)}}\left[\rho_{12} \rho_{13}-\frac{\rho_{2311}\left(\rho_{12}^{2}+\rho_{13}^{2}+2 \rho_{12}^{2} \rho_{13}^{2} B_{1}\right)}{2 \sqrt{\left(1+\rho_{12}^{2} B_{1}\right)\left(1+\rho_{13}^{2} B_{1}\right)}}\right] \frac{d \beta_{1}}{d \theta}
$$

The inequality that $1 \geq \frac{A_{211}}{A_{1}} \frac{d \beta_{211}}{d \beta_{1}} \geq \frac{A_{3112}}{A_{1}} \frac{d \beta_{3112}}{d \beta_{1}} \geq \cdots$ in Eq.(8) suggests several approximate estimates that

$$
\begin{aligned}
& \gamma_{1, \theta}=-\phi\left(-\beta_{S}\right) \frac{A_{1}}{A_{S}} \frac{d \beta_{1}}{d \theta}=-\phi\left(-\beta_{S}\right) \frac{d \beta_{S}}{d \theta} \\
& \gamma_{2, \theta}=\frac{A_{1}}{A_{S}} \frac{d \beta_{1}}{d \theta} \\
& \gamma_{1, \Phi\left(-\beta_{i}\right)}=\frac{\Phi\left(-\beta_{S}\right)}{\Phi\left(-\beta_{i}\right)}=\psi
\end{aligned}
$$

and

$$
\gamma_{2, \beta_{i}}=\frac{\Phi\left(-\beta_{s}\right)}{\Phi\left(-\beta_{i}\right)} \frac{\phi\left(-\beta_{i}\right)}{\phi\left(-\beta_{s}\right)}=\frac{A_{i}}{A_{s}}
$$

[Example 1] Assume that the failure event $F_{S}$ of a system is expressed by $F_{1} \cap F_{2} \cap F_{3}, \rho\left(F_{i}, F_{j}\right)=0.5$ and $P\left(F_{i}\right)=\Phi\left(-\beta_{i}\right)=\Phi(-\beta)$. Design for a target that $\beta_{T}=3.0$.

If $\rho=0$, then $\Phi\left(-\beta_{T}\right)=\Phi(-3)=\Phi(-\beta)^{3}$ and the corresponding $\beta=1.21$. If $\rho=1$, then $\beta=3$. In this connection, a straight line joining the two points is used to obtain an initial reliability index $\beta^{(0)}$; that is, $\beta^{(0)}=1.21+1.79 \rho=2.11$.

Since all the reliability indices should be equally adjusted, $d \beta_{j} / d \beta_{i}=1$. In this case, above approximate factors may have large errors for a system that $\Phi\left(-\beta_{1}\right) » \psi$. Though scarcely ever in actual structural system, this occurs if a system involves a large number of identical $\beta_{i}$ and the performance functions are almost independent. Therefore, this modifies the equations considering $d \beta_{j} / d \beta_{i}=1$. The value of $\zeta$ in Eq.(8) varies from 3 to 1 when $\rho$ increases from 0 to 1 . The values of $\left(A_{211} / A_{1}\right)\left(d \beta_{211} / d \beta_{1}\right)$ are equal to 1 and 0 for $\rho=0$ and 1 , respectively. This observation yields an approximation that $\left(A_{211} / A_{1}\right)\left(d \beta_{211} / d \beta_{1}\right)=(1-\rho)$. Also, an approximation that $\left(A_{3112} / A_{1}\right)\left(d \beta_{3112} / d \beta_{1}\right)=(1-\rho)^{2}$ is acceptable because $\Phi\left(-\beta_{3112}\right)$ is doubly conditional failure probability. Hence, this employs an approximation that $\zeta=1+(1-\rho)+(1-\rho)^{2}$

$=1.75$. Application of approximate sensitivity factors $\gamma_{1, \Phi\left(-\beta_{1}\right)}(=0.0896)$ and $\gamma_{2, \beta_{1}}(=1.1587)$ into Eqs.(3) and (4) yields the same result that $\beta=2.0$. Corresponding $\beta_{s}$ equals 2.995 which is very close to the target.

\section{SERIES SYSTEMS}

The failure event $F_{S}$ of a series system is expressed by the union of basic failure events $F_{i}(i=1,2 \cdots n)$; that is, $F_{S}=F_{1} \cup F_{2} \cup \cdots \cup F_{n}$. Ordering that $\beta_{1} \leq \beta_{2} \leq \beta_{3} \leq \cdots \leq \beta_{n}$ is recommended to minimize probable errors in the calculation.

The failure probability of the system is expressed by

$$
\Phi\left(-\beta_{S}\right)=\sum_{i=1}^{n} \Phi\left(-\beta_{i}\right)-\sum_{i=1}^{n} \sum_{j=2}^{1} \Phi\left(-\beta_{i j}\right)+\sum_{i=1}^{n} \sum_{j=2}^{2} \sum_{k=3}^{n} \Phi\left(-\beta_{i j k}\right)-\cdots \quad(i<j<k<\cdots)
$$

or

$$
\Phi\left(-\beta_{S}\right)=\Phi\left(-\beta_{1}\right)+\Phi\left(-\beta_{1^{\prime} 2}\right)+\cdots+\Phi\left(-\beta_{1^{\prime} 2^{\prime} \cdots(n-1)^{\prime} n}\right)=\Phi\left(-\beta_{1}\right) \psi
$$

in which $\beta_{1^{\prime} 2}=$ the reliability index of $F_{1}{ }^{c} F_{2}$, and $F_{1}{ }^{c}=$ the complement of $F_{1}$.

Since $F_{S}{ }^{c}=F_{1}{ }^{c} F_{2}{ }^{c} \cdots F_{n}{ }^{c}$, the system reliability is expressed by

$$
\Phi\left(\beta_{S}\right)=\Phi\left(-\beta_{1}\right) \Phi\left(-\beta_{\left(2^{\prime} \cap 3^{\prime} \cap \cdots \cap n^{\prime}\right) 11^{\prime}}\right)=\Phi\left(-\beta_{1}\right) \psi^{\prime}
$$


The values of sensitivity factors in Eqs.(22), (23) and (24) are calculated employing formulae for parallel systems above. Approximations based on Eqs.(18) through (21) are also effective for series systems because

$$
\psi \geq 1, d \psi / d \Phi\left(-\beta_{1}\right)<1 \text {, and } 1 » \Phi\left(-\beta_{1}\right)>\Phi\left(-\beta_{12}\right)>>>\Phi\left(-\beta_{12^{\prime}} \quad(n-1)^{\prime} n\right.
$$

[Example 2] Examine the same problem as Example 1 but $F_{S}=F_{1} \cup F_{2} \cup F_{3}$.

If $\rho=0$, then $\Phi\left(\beta_{T}\right)=\Phi(3)=\Phi(\beta)^{3}$ and the corresponding $\beta=3.32$. If $\rho=1$, then $\beta=3$. Therefore, assume an initial reliability index that $\beta^{(0)}=3.32-0.32 \rho=3.16$. The sensitivity factors for Eq. (22) are expressed by, employing $\zeta$ in Example 1,

$$
\begin{aligned}
& \gamma_{1}=3-3 \frac{d \Phi\left(-\beta_{12}\right)}{d \Phi\left(-\beta_{1}\right)}+\frac{d \Phi\left(-\beta_{123}\right)}{d \Phi\left(-\beta_{1}\right)}=3-3 \Phi\left(-\beta_{211}\right)\left[1+\frac{A_{211}}{A_{1}} \frac{d \beta_{211}}{d \beta_{1}}\right]+\Phi\left(-\beta_{2311}\left[1+\frac{A_{211}}{A_{1}} \frac{d \beta_{211}}{d \beta_{1}}+\frac{A_{3112}}{A_{1}} \frac{d \beta_{3112}}{d \beta_{1}}\right]\right. \\
& \gamma_{1 a}=3-3[1+(1-\rho)] \Phi\left(-\beta_{211}\right)+\left[1+(1-\rho)+(1-\rho)^{2}\right] \Phi\left(-\beta_{2311}\right) \\
& \gamma_{2}=\frac{\phi\left(-\beta_{1}\right)}{\phi\left(-\beta_{S}\right)} \cdot \gamma_{1}
\end{aligned}
$$

and

$$
\gamma_{2 a}=\frac{\phi\left(-\beta_{1}\right)}{\phi\left(-\beta_{s}\right)} \cdot \gamma_{1 a}
$$

Approximate $\gamma$ is expressed by the subscript of $a$. Both $\gamma_{1 a}(=2.7774)$ and $\gamma_{2 a}(=1.0637)$ yield the same result that $\beta=3.31$ and corresponding $\beta_{s}=3.005$. The approximate sensitivity factors in this example work well as before.

[Example 3] This is extracted from the example by Ma and Ang ${ }^{6}$. The structure involves four potential failure modes in Table 1. The system failure event $F_{S}$ is expressed by $F_{1} \cup F_{2} \cup F_{3} \cup F_{4}$. The constituent basic random variables $X$ are normally distributed and statistically independent. Assuming that the coefficient of variation $\delta$ of $X$ is constant, the standard deviation $\sigma$ varies in proportion to the average $\mu$. The variables $X_{1}$ and $X_{2}$ express the strength capacities of the structure whereas $X_{3}$ and $X_{4}$ are the external forces on it. Since natural forces are generally uncontrollable, capacities remain as adjustable variables. The parameters of $X$ are given in Table 2. Table 3 represents the matrix of the correlation coefficients. Ordinary reliability analysis yields the estimates that $\Phi\left(-\beta_{S}\right)=0.0388$ and $\beta_{S}=1.765$. Design for a target that $\beta_{T}=2.0$ adjusting the average of $X_{1}$ or $X_{2}$. Also, design for another target that $\beta_{T}=1.5$.

Table 1 Performance functions and reliability indices

\begin{tabular}{llrrrr}
\hline$F_{1}$ & Performance function & $\mu_{1}$ & $\sigma_{1}$ & $\beta_{1}$ & $\Phi\left(-\beta_{1}\right)$ \\
\hline$F_{1}$ & $Z_{1}=4 X_{1}+2 X_{2}-10 X_{3}-15 X_{4}$ & 650 & 357.8 & 1.82 & 0.0346 \\
$F_{2}$ & $Z_{2}=4 X_{1}-15 X_{4}$ & 690 & 311.9 & 2.21 & 0.0135 \\
$F_{3}$ & $Z_{3}=2 X_{1}+4 X_{2}-10 X_{3}-15 X_{4}$ & 890 & 394.0 & 2.26 & 0.0120 \\
$F_{4}$ & $Z_{4}=4 X_{2}-10 X_{3}$ & 920 & 305.0 & 3.02 & 0.0013 \\
\hline
\end{tabular}

Table $2 \mu_{X}$ and $\delta_{X}$

\begin{tabular}{rrr}
\hline$X_{i}$ & $\mu_{r}$ & $\delta_{r}$ \\
\hline$X_{1}$ & 360 & 0.15 \\
$X_{2}$ & 480 & 0.15 \\
$X_{3}$ & 100 & 0.10 \\
$X_{4}$ & 50 & 0.30 \\
\hline
\end{tabular}

Table $3 \rho_{u}$

\begin{tabular}{rrrrr}
\hline & $j=1$ & 2 & 3 & 4 \\
\hline$i=1$ & 1.00 & 0.87 & 0.89 & 0.47 \\
2 & 0.87 & 1.00 & 0.60 & 0.00 \\
3 & 0.89 & 0.60 & 1.00 & 0.77 \\
4 & 0.47 & 0.00 & 0.77 & 1.00 \\
\hline
\end{tabular}

Approximate values of $\gamma_{2, \mu_{1}}$ are 0.00968 and 0.00505 for $X_{1}$ and $X_{2}$, respectively. To save the material used, the average of $X$ that has the largest sensitivity factor should be increased. Hence, the average of $X_{1}$ is increased from 360 to 385 directed by the sensitivity factor. Corresponding system reliability index for the system is 1.9954 , which agrees well with the target reliability. When $\beta_{T}=1.5$, which is less than that of initially assumed system, the average of $X$ that has the smallest sensitivity factor should be decreased in order to minimize the material weight used. In this case, the sensitivity factor indicates the average value 430 of $X_{2}$, which perfectly attain the purpose.

\section{GENERAL SYSTEMS}

The failure event $F$ of a general system is expressed by the union of mutually exclusive intersections. This implies that the system unreliability is expressed by a sum of the probabilities of the intersections of basic failure events. Therefore, its sensitivity factor equals a sum of the sensitivity factors of the intersections involved.

[Example 4] A constant load $T$ is suspended by $n$ identical bars that equally share the load. Assume that the breaking strength of bar $X_{i}(i=1,2 \cdots n)$ is normally distributed with the average $\mu$ and the standard deviation $\sigma(=1.0)$. Assume also that $\rho\left(X_{i}, X_{j}\right)=0$ and $T=1$. Let the target system reliability index $\beta_{T}$ be 2.5 . Express the failure event of the system and then compare the probable errors due to application of approximate sensitivity factors for $n=3$.

If the failure event $W_{1}$ of a branch has failure sequence of bar 1 , bar $2, \cdots$ and bar $n$ in that order, then the event $W_{1}$ is expressed by 


$$
\begin{aligned}
W_{1} & =\left(X_{1}<\frac{T}{n}\right) \cap\left(X_{2}<\frac{T}{n-1}\right) \cap \quad \cap\left(X_{n}<T\right) \cap\left(X_{1}<X_{j}\right) \cap\left(X_{2}<X_{k}\right) \cap \cdots \cap\left(X_{n-1}<X_{n}\right) ; \quad(j=2,3 \cdots n, k=3,4 \cdots n) \\
& =\bigcap_{i=1}^{n} \Phi\left[\frac{-1}{\delta}\left(1-\frac{T}{(n-i+1) \mu}\right)\right] \cap\left(X_{1}<X_{j}\right) \cap\left(X_{2}<X_{k}\right) \cap \cdots \cap\left(X_{n-1}<X_{n}\right) \\
& =\bigcap_{i=1}^{n} \Phi\left[-\beta_{i 112}(1-1)\right] \cap\left(X_{1}<X_{j}\right) \cap\left(X_{2}<X_{k}\right) \cap \cdots \cap\left(X_{n-1}<X_{n}\right)
\end{aligned}
$$

There are $n$ ! possible paths: Since the intersection of the constraints on the variables in every two branches is empty, the branches are mutually exclusive. Therefore, the failure probability of the system is $n ! P\left(W_{1}\right)$.

If the constraints on the variables are eliminated, then $W_{1}$ is positively correlated to $W$, for all the combinations of $i$ and $j$. As an example, let us examine the contents of $F_{S}$ for $n=3$. The failure event of the system is expressed by

$$
F_{S}=\xi_{1} \cup \xi_{2} \cup \xi_{3}
$$

where

$$
\begin{aligned}
& \xi_{1}=E_{1}\left(F_{2} G_{3} \cup F_{3} G_{2}\right), \xi_{2}=E_{2}\left(F_{1} G_{3} \cup F_{3} G_{1}\right), \xi_{3}=E_{3}\left(F_{1} G_{2} \cup F_{2} G_{1}\right), \\
& E_{1}=\left(X_{1}<T / 3\right), F_{1}=\left(X_{1}<T / 2\right), G_{1}=\left(X_{1}<T\right)
\end{aligned}
$$

Since $E_{\imath} \subset F_{\imath} \subset G_{\imath}, E_{\imath} F_{\imath}=E_{\imath}, E_{\imath} \cup F_{\imath}=F_{\imath}$ and the like. Thus,

$$
\xi_{1} \xi_{2}=E_{1} E_{2} G_{3} \text { and } \xi_{1} \xi_{2} \xi_{3}=E_{1} E_{2} E_{3}
$$

Substituting these relationships into Eq.(30), the following expression is obtained.

$$
P\left(F_{S}\right)=6 P(E) P(F) P(G)-3 P(E) P(F)^{2}-3 P(E)^{2} P(G)+P(E)^{3}
$$

Initially assumed reliability index $\beta_{1}{ }^{(0)}$ of 1.3 is derived from a rough estimate that $\Phi(-2.5)=6 \Phi\left(-\beta_{1}\right)^{3}$.. In this case, $\Phi\left(-\beta_{s}{ }^{(0)}\right)=0.008468$ and $\beta_{s}{ }^{(0)}=2.39$. The sensitivity factors are expressed by

$$
\begin{aligned}
& \gamma_{1, \mu}=\frac{d \Phi\left(-\beta_{S}{ }^{(0)}\right)}{d \mu}=\sum_{i=1}^{3} \frac{d \Phi\left(-\beta_{S}{ }^{(0)}\right)}{d \Phi\left(-\beta_{1}\right)} \frac{d \Phi\left(-\beta_{1}\right)}{d \beta_{1}} \frac{d \beta_{1}}{d \mu}=\sum_{i=1}^{3}-\phi\left(-\beta_{1}\right) \frac{d \Phi\left(-\beta_{S}{ }^{(0)}\right)}{d \Phi\left(-\beta_{1}\right)} \frac{d \beta_{1}}{d \mu} \\
& \gamma_{2, \mu}=\frac{d \beta_{S}{ }^{(0)}}{d \mu}=\frac{-\gamma_{1, \mu}}{\phi\left(-\beta_{S}{ }^{(0)}\right)}
\end{aligned}
$$

Approximate sensitivity factors are estimated using Eqs.(18) and (19). Table 4 compares four sensitivity factors and corresponding system reliability indices. Note that the sensitivity factors for $\beta_{S}$ work well and approximate sensitivity factor for $\beta_{s}$ is preferable.

\begin{tabular}{cllll}
$\ldots$ & \multicolumn{5}{l}{ Table 4 } & $\gamma, \mu, \beta_{s}$ and $\Phi\left(-\beta_{S}\right)$ \\
\hline & $\gamma_{1}$ & $\gamma_{1 a}$ & $\gamma_{2}$ & $\gamma_{2 a}$ \\
\hline$\gamma$ & -0.03694 & -0.0393 & 1.61 & 1.71 \\
$\mu$ & 1.69 & 1.687 & 1.7 & 1.694 \\
$\beta_{S}$ & 2.484 & 2.48 & 2.5 & 2.49 \\
$\Phi\left(-\beta_{S}\right)$ & 0.0065 & 0.006563 & 0.006214 & 0.006385 \\
\hline
\end{tabular}

\section{CONCLUDING REMARKS}

This paper develops a method to design a system that has prescribed reliability adjusting the capacity of suitably chosen element(s) directed by the sensitivity factor. The sensitivity factor for the reliability index generally works better than that for the failure probability. Approximate sensitivity factors in the examples afford the prescribed system reliability through simple calculation.

\section{REFERENCES}

1) American Instutute of Steel Construction, Inc Load \& Resistance Factor Desıgn Specification for Structural Steel Buildings, 1983

2) Architectural Insutute of Japan . Recommendation for Limit State Design of Steel Structures, 199810

3) Bjerager, $P$ and Krenk, $S$ Parametnc Sensituvity in First Order Relıabılity Analysıs, Journal of Engineenng Mechanics, ASCE, 115(7), pp.1577-1582, 1989

4) Ronold, Knut O Sensitivity Measures in Nested Reliability Analyses, Journal of Engineenng Mechanics, ASCE, 117(9), pp.2101-2113, 1991.

5) Terada, S and Takahashı, T. . Fallure Conditioned Relıabılıty Index, Journal of Structural Engineerıng, ASCE, 114(4), pp 942-952, 1988

6) Ma, H -F and Ang, A H -S Relıabılıty Analysıs of Redundant Ducule Structural Systems, Structural Research Senes No, 494, Unıversity of Illınoıs at Urbana-Champaign, 1981 


\section{和文要約}

1. 序

「荷重・耐力係数設計法」は，鋼構造部材とその接合部に所定の 信頼度を与える設計法である. しかし仮に幾つかの部材が壊れたと しても，系全体としては生き残る可能性が高い，従って，所定の系 信頼度を保証する簡単な設計法の開発が必要である. 本論では, 感 度係数により系信頼度を調節する一法を誘導する.

\section{2. 感度係数}

系破壊確率に対するパラメータ $\theta$ の感度係数 $\gamma_{1, \theta}$ を，(1)式で定義す る.ここに， $\beta_{s}$ は系信頼性指標， $($ ( )は標準正規累積分布関数であ る. 別に, $\beta_{s}$ に対する $\theta$ の感度係数 $\gamma_{2, \theta}$ を(2)式で定義する. ここに, $\phi($ )は標準正規確率密度関数である.

パラメータとしては, 性能関数中の係数, 基礎確率変数の平均 值 $\mu$ と標準偏差 $\sigma$, 基本破壊モ一ド $F$, の信頼性指標 $\beta$ ，とその破壊確率 $\Phi\left(-\beta_{i}\right)$ 等がある. (1)式は， $\theta=\Phi\left(-\beta_{i}\right)$ に適用し，それ以外の $\theta$ には(2)式 を用いる，系信頼度は(3)，(4)式で調節される。

\section{3. 並列系}

並列系の破壊事象は， $F_{S}=\cap_{t=1}{ }^{n} F_{1}$ で表わされる，系の破壊確率 $P\left(F_{S}\right)$ は，(6)式の条件付き信頼性指標を用いて(5)式で表わされる. 式中の $\rho_{i j}$ は， $F$, と $F_{j}$ の間の相関係数である. 計算上, $\beta_{1} \geq \beta_{2} \geq \beta_{3} \geq \cdots$ $\geq \beta_{n}$ となるように符号をふろう.

$\Phi\left(-\beta_{S}\right)$ に対する感度俰数 $\gamma_{1, \theta}$ は，(7)式で表わされる. 式中のらは,

(8)式で表わされる. $\theta=\Phi\left(-\beta_{1}\right)$ の場合の感度係数 $\gamma_{1, \Phi(-\beta 1)}$ は(9)式とな る. $\beta_{s}$ に対する感度係数 $\gamma_{2, \theta}$ は(7)式を(2)式に代入すれば求まり, (10), (11)式で表わされる.

条件付信頼性指標の微係数 $d \beta_{211} / d \theta$ は, (13)式の係数 $C_{12}$ を用いて, (12)式で表わされる.これと同様に， $d \beta_{312} / d \theta は(15) \sim(17)$ 式の倸数 を用いて(14)式で計算できる. (18)〜(21)式は, 感度係数の近似式で ある.

[例題1] 系の破壊は, $F_{S}=F_{1} \cap F_{2} \cap F_{3}$ で表わされる. $P\left(F_{1}\right)=\Phi(-$ $\left.\beta_{1}\right)=\Phi(-\beta), \rho_{15}=\rho=0.5$ とする. 目標信頼度は $\beta_{T}=3.0$ である. 近似式の 誤差を調べる.

$d \beta / d \beta_{t}=1$ に基づく $\beta$ の初期值として, $\beta^{(0)}=1.21+1.79 \rho=2.11$ を仮定 した. $\gamma_{1, \Phi(-\beta 1)} \fallingdotseq 00896$ と $\gamma_{2, \beta 1} \fallingdotseq 1$ 1587より求めた $\beta$ は等しく, 20 であ る. 系信頼度は2.995であり，目標值にほほ一致した。

\section{4. 直列系}

直列系の破壊は， $F_{S}=\cup_{1=1}{ }^{n} F_{1}$ で表わされる．計算誤差を減らすため に, $\beta_{1} \leq \beta_{2} \leq \beta_{3} \leq 、 \leq \beta_{n}$ となるように符号をふる. その破壊確率は， (22)式または(23)式で表わされる. 系信頼度は, 余事象を用いた(24) 式で表わされる.これらの式の感度係数は, 並列系で得られた結果 を式中の積事象に代入すれば求められる. また，(18)〜(21)式に基づ く近似式も有効である.

[例題 2] $F_{S}=F_{1} \cup F_{2} \cup F_{3}$ とする. 他は [例題1]と同じ条件で $\beta_{T}=3$ 0の系を設計する.

$\beta$ の初期值として， $\beta^{(0)}=3.32-0.32 \rho=316$ を仮定する. (22)式の破壊 確率について計算すれば，(25)〜(28)式の感度係数が得られる．添字 $a$ は近似を表わす.

$\gamma_{1 a}(=2.7774)$ と $\gamma_{2 a}(=10637)$ より求めた $\beta$ 等しく, 3.31 である. こ れに相当する系信頼性指標 $\beta_{s}$ は3.005であり, 目標値にほほ一致し た.

[例題3]この構造物の破壊は, $F_{S}=F_{1} \cup F_{2} \cup F_{3} \cup F_{4}$ で表わされる. その性能関数と信頼性指標をTable 1に示す. 確率変数 $X$ は, 互いに独 立な正規確率変数である. 変動係数を一定と仮定すると, 標準偏差 は平均値に比例する. $X_{1}$ と $X_{2}$ は容量を, $X_{3}$ と $X_{4}$ は需要を示す確率変 数である. 一般に需要は管理できないので, 容量を加減する. 変数 のパラメータをTable 2に示す. Table 3は性能関数間の相関係数で ある. $\Phi\left(-\beta_{S}\right)=00388, \beta_{S}=1.765$ と計算された. $\beta_{T}=2.0$ および $\beta_{T}=1.5$ に対して設計する.

$\gamma_{2, \mu 1}=0.00968, \gamma_{2, \mu 2}=0.00505$ である. 資材節約のために，数值の大 きい $\mu_{1}$ を385に增す. その時, $\beta_{S}=19954$ となり， $\beta_{T}$ に良く一致し た. $\beta_{T}=1.5$ の場合は $\mu_{2}=430$ とするのが経済的であり, $\beta_{S}=1.5$ となつ た.

\section{5. 一般采}

一般系の破壊は，排反な積事象の和で表わされる. 従って, 系の 感度係数は排反な積事象の感度係数の和に等しい.

[例題4] 荷重 $T$ を, $n$ 本の並行な棒で吊る. 荷重は総ての棒に等し く配分される. 棒の破断強度Xの平均値は $\mu$, 標準偏差のは1であり, 正規分布を仮定する. $n=3, T=1$ として,$\beta_{T}=2.5$ の系を設計する.

棒 $1 ， 2 ， 3 ， \cdot n$ の順に破壊が起こる事象 $W_{1}$ は，(29)式で表わさ れる. $P\left(F_{S}\right)=n ! P\left(W_{1}\right)$ である.

(29)式中の確率変数Xの大小についての条件をとり除けば, 経路の 破壊事象は互いに排反ではなくなる. $n=3$ の場合の破壊事象は(30)式 で表わされる，系破壊確率は(31)，(32)式を(30)式に代入して，(33) 式のごとく求められる.

'略算に基づき, 初期值 $\beta_{1}{ }^{(0)}=13$ を仮定する. 感度俰数は(34), (35) 式で表わされる. 近似感度係数は(18), (19)式を用いて求められる. 結果をTable 4 に示す．信頼性指標 $\beta_{s}$ の感度係数が良い結果をもたら している.

\section{6. 結 語}

感度係数により系信頼度を調節する一法を導いた，系信頼性指標 に対する感度倸数は，破買確率に対するそれに比べて優れている. 近似感度係数は計算が簡単であり, 例題では十分に機能を発揮し た．通常の解析に若干の計算を付加すれば，信頼度の調整ができ る. 